\title{
Assessment of Remaining Recoverable Oil in Selected Major Oil Fields of the Permian Basin, Texas and New Mexico
}

he U.S. Geological Survey
(USGS) recently completed an
estimate of technically recoverable,
conventional oil in selected oil fields
in the Permian Basin in west Texas
and southeastern New Mexico. The
mean total volume of potential ad-
ditional oil resources that might be
added using improved oil-recovery
technologies was estimated to be
about 2.7 billion barrels of oil.

\section{Introduction}

A team of U.S. Geological Survey (USGS) scientists recently completed an assessment of the potential for additions to oil reserves that could result from applying improved oil-recovery technologies in 18 large oil fields in the Permian Basin in west Texas and southeastern New Mexico. During the Paleozoic Era (542 to 251 million years ago), the region was an extensive complex of carbonate shelves and platforms (areas where shallow-marine limestones were deposited), separated by intervening basins, that lay along the southern margin of North America. These include the Northwest Shelf, Central Basin Platform, and Eastern Shelf and the Delaware and Midland Basins.

The oil fields analyzed in this study include some of the larger fields in the conterminous United States and were discovered between 1923 and 1950 . Individual estimates of recoverable oil volumes in the 18 fields range from about 430 million barrels of oil (MMBO) to 3 billion barrels of oil (BBO) as of 2006. Estimates of volumes of original oil in place (OOIP) in individual fields range from about $700 \mathrm{MMBO}$ to more than 5 BBO. Between 1979 and 2004, estimates

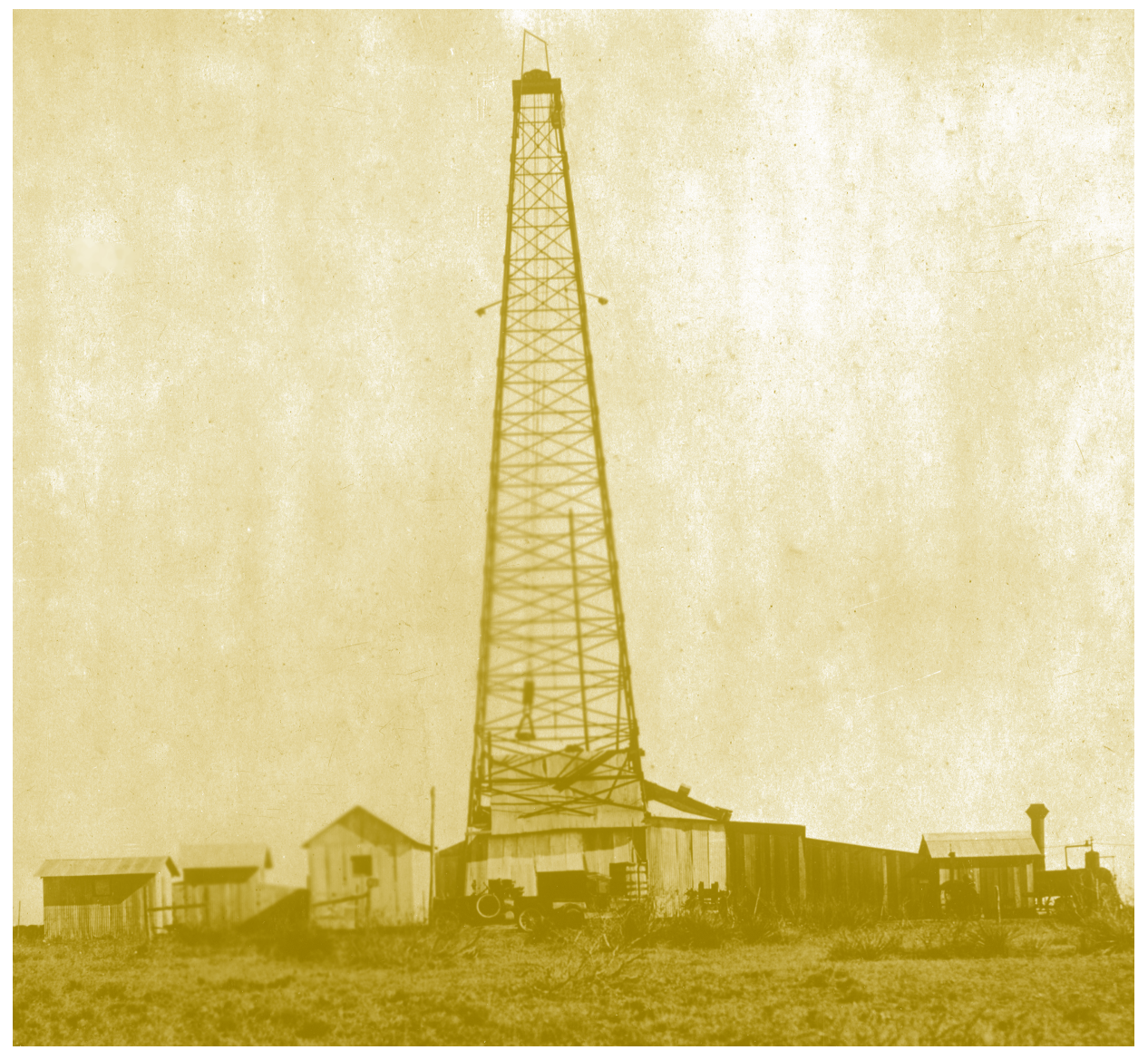

The Permian Basin in west Texas and southeastern New Mexico includes some of the largest oil fields in the conterminous United States. U.S. Geological Survey scientists recently completed an assessment of the potential for additions to oil reserves that could result from applying improved oil-recovery technologies in 18 large oil fields in the basin that were discovered between 1923 and 1950. This photograph taken in 1923 shows the Newnham well (Farmers Oil Company) in Odessa, Texas (U.S. Geological Survey photograph by W.B. Lang).

of the volume of recoverable oil in these 18 fields increased by $4.7 \mathrm{BBO}$ (from data in Nehring, 2007).

The principal oil reservoirs in the Permian Basin are carbonate shelf and platform strata with variable porosity and generally low permeability. Primary recovery efficiencies were low, typically 10 to 20 percent of the OOIP. Beginning in about 1950, waterfloods (water injected into reservoirs to force oil out) were increasingly used to improve oil recovery. Starting in about 1970, carbon dioxide $\left(\mathrm{CO}_{2}\right)$ injection began to be used in some larger fields to increase oil recovery. Recovery efficiency has reached 50 to 60 percent in a few fields with extensive $\mathrm{CO}_{2}$ injection, particularly in reservoirs within the Permian (299 to 251 million years ago) San Andres Limestone on the Northwest 


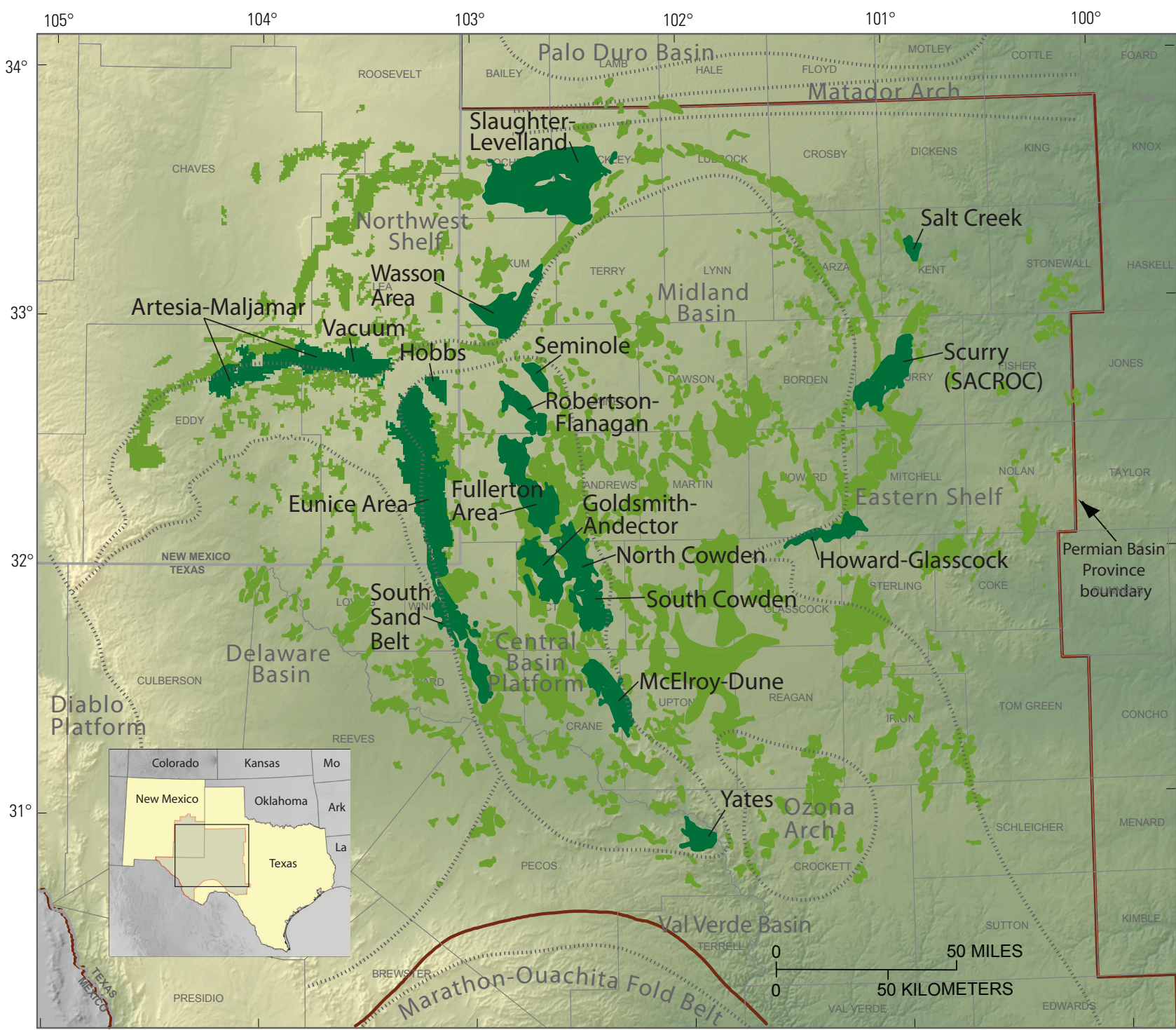

Map showing oil fields (green) in the Permian Basin of west Texas and southeastern New Mexico. Oil fields individually assessed are shown in darker green and labeled. Most of the assessed oil fields are composites, consisting of aggregated fields and reservoirs, indicated on the map by hyphenated field names or by the term "Area." Compiled from maps of individual oil plays in Dutton and others (2004); gray hachured lines are paleogeographic shelf and basin boundaries. SACROC, Scurry Area Canyon Reef Operators Committee.

Shelf and Central Basin Platform and in reef limestones of the Pennsylvanian (318 to 299 million years ago) Canyon Group in the Midland Basin. Because the supply of $\mathrm{CO}_{2}$ for injection is limited and injection adds substantial expense to operators' costs, operators of many of the fields studied have only used waterfloods to increase recovery, and the fields therefore still have relatively low recovery efficiencies. In addition, many less-exploited reservoirs have less ideal reservoir properties than those in which advanced recovery technologies have been used. The USGS assessment estimates the range of additional volumes of oil reserves that could be added within the 18 fields analyzed by using $\mathrm{CO}_{2}$ injection or other advanced oil-recovery technologies. The analysis was made without regard to cost or to availability of $\mathrm{CO}_{2}$.

Recently, $\mathrm{CO}_{2}$ injection has begun in several fields within a zone of low oil saturation below the main reservoir interval, called the "residual oil zone." These efforts have met with some success, but because detailed data with which to evaluate them are not yet available, the USGS analysis did not consider potential reserve additions from the residual oil zone. It is possible that such additions could be substantial.

\section{Methodology}

Of the 18 oil fields (or composites of related fields) in the Permian Basin evaluated by the USGS, most exhibited significant additions to reserves from 1982 to 2006. Production and reserves information, as of 2006, came from a proprietary commercial database. To assess the potential for future additions to reserves, an evaluation was made of each field (Klett and others, 2011). The geology of each field was analyzed, and its 
Key assessment data for oil fields individually assessed within the Permian Basin, west Texas and southeastern New Mexico.

[MMBO, million barrels of oil (BBO, billion barrels of oil; $1 \mathrm{BBO}=1,000 \mathrm{MMBO}$ ). Estimated recovery efficiency is potentially recoverable proportion of original oil in place. SACROC, Scurry Area Canyon Reef Operators Committee]

\begin{tabular}{|c|c|c|c|c|c|c|c|c|}
\hline Field & $\begin{array}{l}\text { Components } \\
\text { (reservoir names in parentheses) }\end{array}$ & $\begin{array}{l}\text { Known } \\
\text { recoverable oil } \\
(2004)^{1} \\
(\mathrm{MMBO})\end{array}$ & \multicolumn{3}{|c|}{$\begin{array}{l}\text { Estimated original oil in place } \\
\qquad \text { (MMBO) }\end{array}$} & \multicolumn{3}{|c|}{ Estimated recovery efficiency } \\
\hline Artesia-Maljamar & $\begin{array}{l}\text { Artesia, Loco Hills, Grayburg-Jackson, Maljamar, Pearsall (Queen, } \\
\text { Grayburg, San Andres, Glorieta reservoirs) }\end{array}$ & 466 & 1,000 & 1,200 & 1,800 & 45 & 50 & 55 \\
\hline Eunice Area & $\begin{array}{l}\text { Eunice-Monument, S. Eunice, N. Monument, Eumont, Fowler, Jalmat, } \\
\text { Justis, Langlie-Mattix, Oil Center, Teague, Weir (all reservoirs) }\end{array}$ & 1,005 & 4,200 & 4,500 & 5,000 & 35 & 40 & 45 \\
\hline Fullerton Area & $\begin{array}{l}\text { Fullerton, E. Fullerton (San Andres, Clear Fork, Wolfcamp, Ellenburger } \\
\text { reservoirs); University Block } 13 \text { (Wolfcamp, Devonian, Ellenburger } \\
\text { reservoirs) }\end{array}$ & 526 & 1,500 & 1,600 & 2,000 & 33 & 36 & 40 \\
\hline Goldsmith-Andector & $\begin{array}{l}\text { Goldsmith, Lawson, Andector (all reservoirs); TXL (upper Clear Fork } \\
\text { reservoir) }\end{array}$ & 1,005 & 1,850 & 2,100 & 2,600 & 40 & 45 & 50 \\
\hline Hobbs & Hobbs, Bowers, (all reservoirs) & 473 & 800 & 1,000 & 1,300 & 50 & 55 & 60 \\
\hline Howard-Glasscock & $\begin{array}{l}\text { Howard Glasscock (Yates, Seven Rivers, Queen, Grayburg, San Andres } \\
\text { reservoirs) }\end{array}$ & 509 & 1,500 & 1,600 & 1,800 & 35 & 38 & 50 \\
\hline McElroy-Dune & $\begin{array}{l}\text { McElroy, Dune (Grayburg, San Andres, Wolfcamp, Bend 8960, Devonian } \\
\text { reservoirs) }\end{array}$ & 876 & 3,300 & 3,600 & 4,000 & 25 & 33 & 40 \\
\hline North Cowden & $\begin{array}{l}\text { North Cowden (Grayburg, San Andres, Holt, Canyon, Strawn } \\
\text { reservoirs); Venteam (Wolfcamp, Strawn, Ellenburger reservoirs) }\end{array}$ & 758 & 1,400 & 1,600 & 2,100 & 48 & 50 & 60 \\
\hline Robertson-Flanagan & $\begin{array}{l}\text { Robertson N, Robertson, North Riley, Harris, Flanagan (Clear Fork, } \\
\text { Canyon, Devonian, Ellenburger reservoirs) }\end{array}$ & 560 & 1,500 & 1,600 & 2,000 & 30 & 35 & 40 \\
\hline Salt Creek & Salt Creek (Canyon reservoir) & 416 & 680 & 700 & 730 & 60 & 63 & 65 \\
\hline Scurry (SACROC) & $\begin{array}{l}\text { Kelly-Snyder, Diamond-M, North Snyder, (San Andres, Clear Fork, } \\
\text { Wichita-Albany, Wolfcamp, Cisco Sand, Canyon, Strawn reservoirs) }\end{array}$ & 1,735 & 3,000 & 3,100 & 3,300 & 55 & 62 & 65 \\
\hline Seminole & Seminole (San Andres, San Angelo, Wolfcamp, Devonian reservoirs) & 784 & 1,250 & 1,300 & 1,400 & 55 & 60 & 65 \\
\hline Slaughter-Levelland & $\begin{array}{l}\text { Slaughter, Levelland, Dean, Rhodes (San Andres, Clear Fork, Wichita- } \\
\text { Albany, Abo, Strawn reservoirs) }\end{array}$ & 2,380 & 4,200 & 4,600 & 5,600 & 48 & 50 & 60 \\
\hline South Cowden & $\begin{array}{l}\text { Cowden, South Cowden, Foster, Johnson (Grayburg, San Andres, } \\
\text { Glorieta, Cisco, Canyon, Devonian, Ellenburger reservoirs) }\end{array}$ & 656 & 2,100 & 2,200 & 3,000 & 30 & 35 & 40 \\
\hline South Sand Belt & $\begin{array}{l}\text { North Ward Estes, Scarborough, Hendrick, Kermit, Halley, Emperor, } \\
\text { H.S.A, Weiner (Yates, Seven Rivers, Queen, Grayburg, Holt, Glorieta, } \\
\text { Clear Fork, Wichita-Albany, Wolfcamp, Canyon, Thirtyone, Fusselman, } \\
\text { Montoya, Simpson, McKee, Ellenburger reservoirs) }\end{array}$ & 990 & 2,900 & 3,000 & 3,500 & 35 & 40 & 45 \\
\hline Vacuum & $\begin{array}{l}\text { Vacuum; N. and Middle Vacuum (Yates, Grayburg-San Andres, Glorieta, } \\
\text { Brinebry, Drinkard, Bone Spring, Abo, Wolfcamp, Cisco, Canyon, Atoka, } \\
\text { Wristen reservoirs) }\end{array}$ & 745 & 1,600 & 1,800 & 2,100 & 45 & 50 & 55 \\
\hline Yates & Yates, Toborg (Artesia, Grayburg, San Andres reservoirs) & 1,775 & 4,000 & 4,300 & 5,000 & 40 & 45 & 55 \\
\hline
\end{tabular}

${ }^{1}$ Nehring (2007); 2004 values are shown because 2006 values are proprietary.

development history reviewed. Estimates of OOIP in each field were made using information available from various published and proprietary sources. Potential growth was evaluated by estimating the range of recovery efficiency that might be realized with further application and refinement of existing technologies, regardless of economic factors or availability of $\mathrm{CO}_{2}$.

\section{Results}

The USGS analysis indicates that there is significant remaining potential for additions to oil reserves in the 18 Permian Basin oil fields evaluated. The largest reservoirs - the San Andres, Grayburg, and Canyon-have contributed the most to growth to oil reserves in recent decades and have already achieved high recovery efficiencies with the extensive use of waterflood and $\mathrm{CO}_{2}$ recovery programs. Reserves within them are not likely to grow as much in most of the fields as within less intensively developed, deeper reservoirs, but the magnitude of additions may be less than in the past because reservoir character in the deeper reservoirs is poorer. The mean USGS estimate is that an additional 2.68 $\mathrm{BBO}$ could be added to reserves in the 18 fields evaluated. There is little chance that reserve additions could be more than 4.5 BBO or less than 1.05 BBO. These volumes may not be currently economic to recover and will require a significantly greater supply of $\mathrm{CO}_{2}$ for injection than is presently available.

Oil reserves will also continue to be added in fields within the Permian Basin that were not included in this analysis. Most such fields are smaller than the fields studied, and their additions to reserves will also be smaller, although they may be significant. Statistical methods, like those used in previous USGS reserve growth estimates, are being used to approximate a volume of additional reserves that might be expected to come from these smaller fields.

\section{References Cited}

Dutton, S.P., Kim, E.M., Broadhead, R.F., Breton, C.L., Raatz, W.D., Ruppel, S.C., and Kerans, C., 2004, Play analysis and digital portfolio of major oil reservoirs in the Permian BasinApplication and transfer of advanced geological and engineering technologies for incremental production opportunities, final report: Austin, Texas, Bureau of Economic Geology, and Socorro, New Mexico, New Mexico Institute of Mining and Technology, accessed March 8, 2012, at http://www. beg.utexas.edu/resprog/permianbasin/ playanalysis.htm.

Klett, T.R., Attanasi, E.D., Charpentier, R.R., Cook, T.A., Freeman, P.S., 


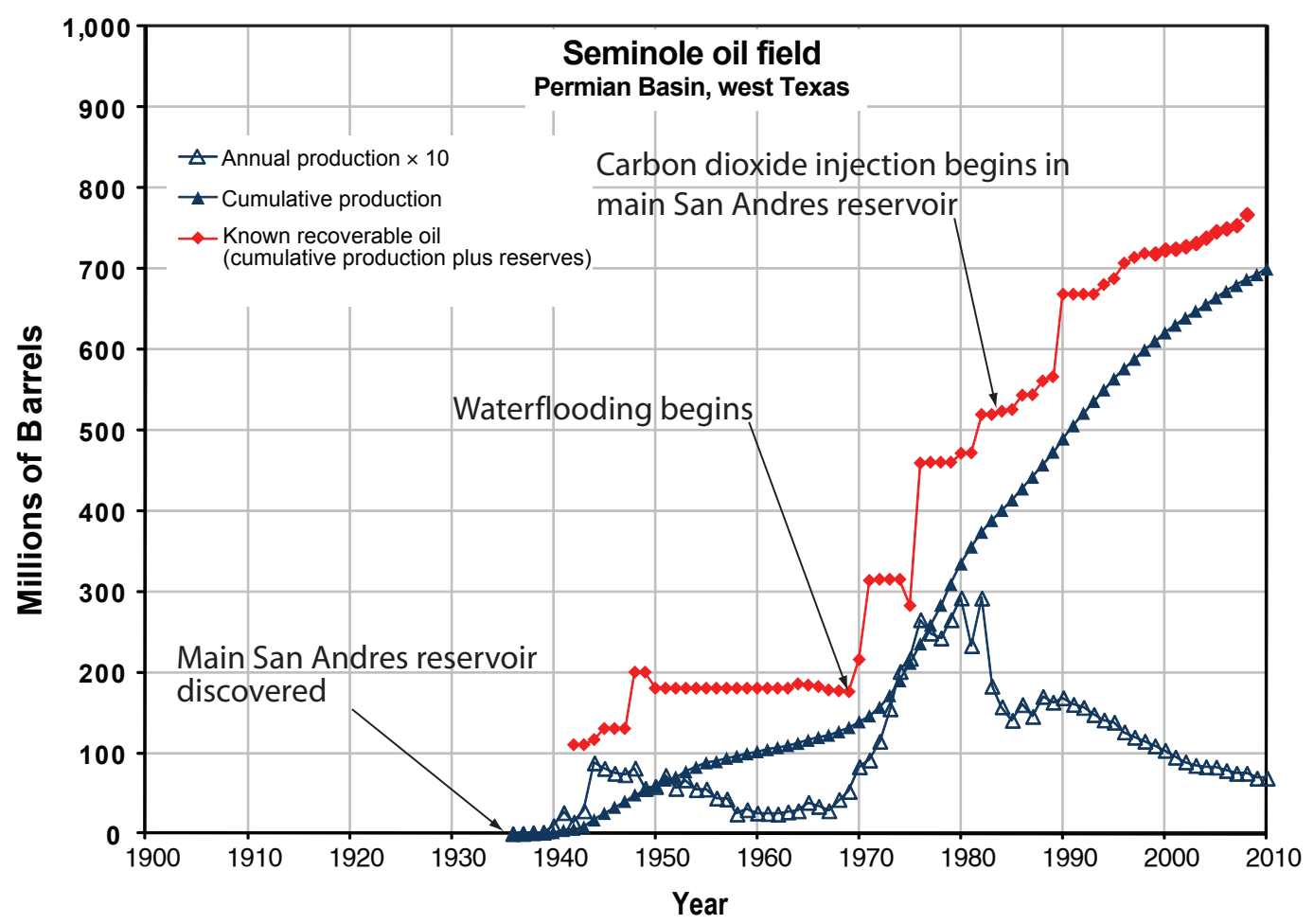

The history of Seminole oil field on the Central Basin Platform in west Texas is typical of many fields in the Permian Basin. By 2010, the field had produced about 700 million barrels of oil (MMBO), mostly from carbonate reservoirs of the Permian San Andres Formation. Before waterflooding began in the late 1960s, production was declining and the volume of oil expected to be recovered was less than 200 MMBO, about 14 to 17 percent of the approximately 1.2 to 1.4 billion barrels of oil originally in place. With waterflooding, production increased significantly and the volume of recoverable oil grew to more than $500 \mathrm{MMBO}$. In the early 1980s, carbon dioxide injection began, slowing the decline in production and increasing the recoverable volume to more than $750 \mathrm{MMB0}$. This study concluded that reserves in this field are not likely to grow much more. (Production and reserves data from Oil and Gas Journal and the Texas Railroad Commission; reserves after 1998 approximated by 10 times annual production. Annual production plotted at 10 times actual value for legibility.)
Gautier, D.L., Le, P.A., Ryder, R.T., Schenk, C.J., Tennyson, M.E., and Verma, M.K., 2011, New U.S. Geological Survey method for the assessment of reserve growth: U.S. Geo- logical Survey Scientific Investigations Report 2011-5163, 8 p., available at http://pubs.usgs.gov/sir/2011/5163/.

Nehring, R. 2007, The oil recovery growth of the Permian Basin, USA:
Colorado Springs, Colo., Nehring Associates, accessed March 7, 2012, at http://www.nehringdatabase.com/ images/pdfs/Permian\%20Growth\%20 Poster.pdf.

\section{Assessment results for volume of additional oil potentially recoverable from selected oil fields in the Permian Basin, west Texas and southeastern New Mexico (technically recover- able resources).}

[Mean estimates add to a total mean, but fractile values for individual fields are not additive; fractiles (non-additive) for the entire group of fields are shown in the bottom row highlighted in yellow. MMBO, million barrels of oil (BBO, billion barrels of oil; $1 \mathrm{BBO}=1,000 \mathrm{MMBO}$ ). F95 denotes a 95 -percent chance of at least the amount tabulated, F50 denotes a 50-percent chance, and F5 denotes a 5-percent chance. Negative values indicate a chance that reserves could decrease from currently estimated values]

\begin{tabular}{|c|c|c|c|c|c|}
\hline \multirow{2}{*}{ Field } & \multirow{2}{*}{ Reservoir(s) } & \multicolumn{4}{|c|}{ Oil (MMBO) } \\
\hline & & F95 & $\mathrm{F} 50$ & F5 & Mean \\
\hline Artesia-Maljamar & All reservoirs & 44 & 132 & 300 & 146 \\
\hline Eunice Area & All reservoirs & 633 & 810 & 1001 & 812 \\
\hline Fullerton & All reservoirs & -9 & 41 & 122 & 47 \\
\hline Goldsmith-Andector & All reservoirs & 27 & 137 & 285 & 144 \\
\hline Hobbs & All reservoirs & -25 & 59 & 168 & 64 \\
\hline Howard-Glasscock & All reservoirs & 62 & 137 & 248 & 144 \\
\hline McElroy-Dune & All reservoirs & 92 & 290 & 489 & 291 \\
\hline North Cowden & All reservoirs & -33 & 70 & 235 & 81 \\
\hline Robertson-Flanagan & All reservoirs & -11 & 54 & 139 & 58 \\
\hline Salt Creek & All reservoirs & -7 & 9 & 25 & 9 \\
\hline Scurry & All reservoirs & -28 & 104 & 218 & 101 \\
\hline Seminole & All reservoirs & -44 & 7 & 61 & 7 \\
\hline Slaughter-Levelland & All reservoirs & -289 & -44 & 318 & -22 \\
\hline \begin{tabular}{|l|} 
South Cowden \\
\end{tabular} & All reservoirs & 29 & 117 & 250 & 126 \\
\hline South Sand Belt & All reservoirs & 61 & 175 & 305 & 179 \\
\hline \begin{tabular}{|l|} 
Vacuum \\
\end{tabular} & All reservoirs & 68 & 161 & 272 & 164 \\
\hline \multirow[t]{2}{*}{ Wasson Area } & Clear Fork and older reservoirs & -10 & 50 & 131 & 54 \\
\hline & San Andres and Glorieta reservoirs & -57 & 22 & 114 & 25 \\
\hline Yates & All reservoirs & 4 & 233 & 532 & 247 \\
\hline All evaluated fields & All evaluated reservoirs & 1,052 & 2,611 & 4,512 & 2,676 \\
\hline
\end{tabular}

Reserve Growth Assessment Team: Marilyn E. Tennyson, Troy A. Cook, Ronald R. Charpentier, Donald L. Gautier, Timothy R. Klett, Mahendra K. Verma, Robert T. Ryder, Emil D. Attanasi, Philip A. Freeman, and Phoung A. Le

Edited by James W. Hendley II Graphic design by Steve Scott

\section{For Further Information}

Supporting geologic studies of total petroleum systems and assessment units and reports on the methodology used in this assessment, as well as the assessment results, are available at the USGS

Energy Resources Program Web site: http://energy.usgs.gov/ or contact

Marilyn E. Tennyson (tennyson@usgs.gov)

This Fact Sheet and any updates to it are available online at

http://pubs.usgs.gov/fs/2012/3051/ 